\title{
On the Meaning of 'Waste': Review and Definition
}

Matthias Thürer (corresponding author), Ivan Tomašević and Mark Stevenson

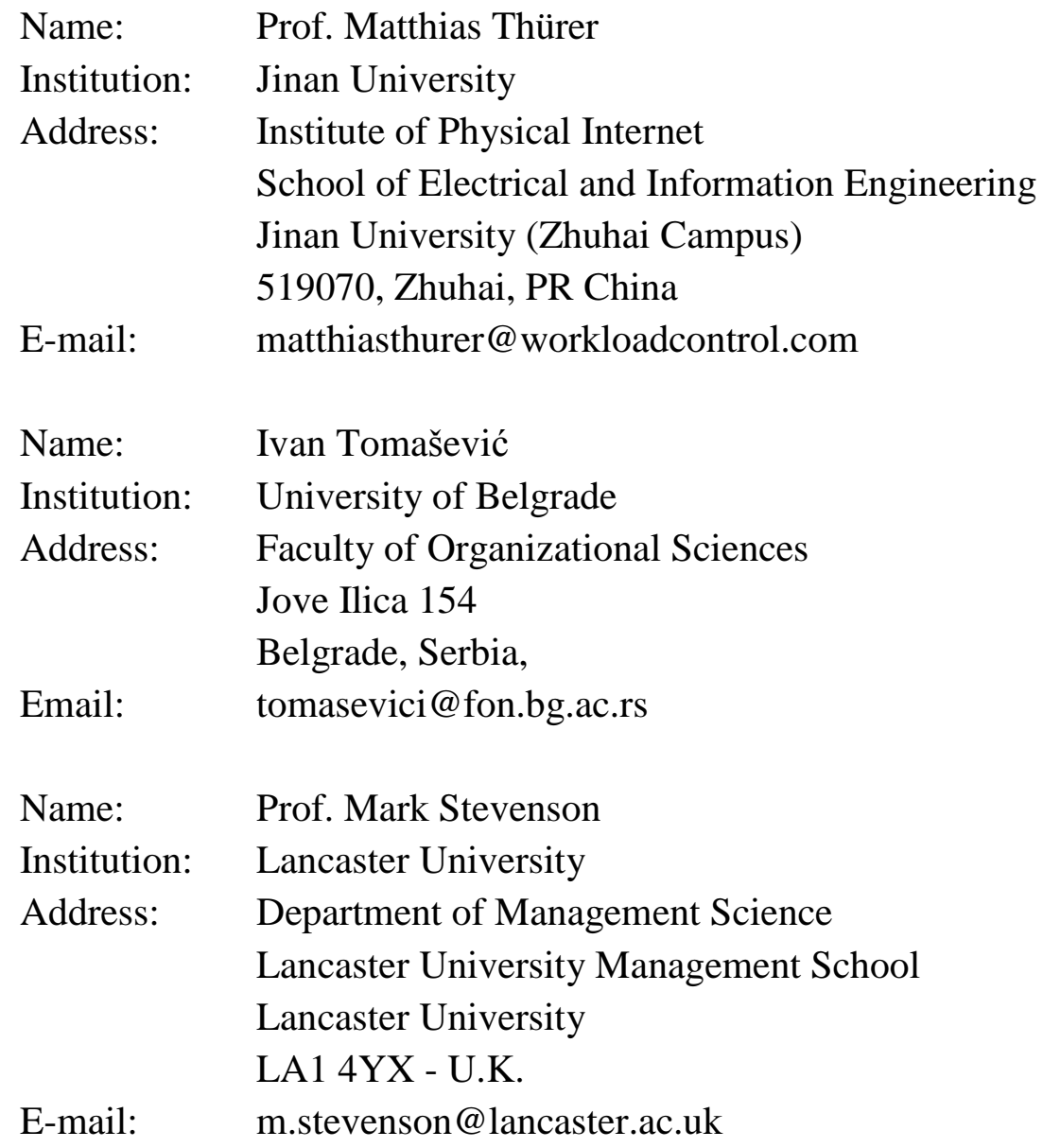




\title{
On the Meaning of 'Waste': Review and Definition
}

\begin{abstract}
Waste reduction is one of the main principles of lean, but it has been taken for granted that we have a common understanding of what waste means. We first present a critical, qualitative discussion that identifies four distinct waste concepts. We then conduct a systematic review of the literature that examines the different uses of these concepts. We find that only the classic concept of the seven wastes and the concept of waste as non-value adding activity are widely applied. However, both concepts are, at times, not only incompatible but used in a way that leads to open contradiction. A new definition, centered on an efficient, timely transformation process seeks to consolidate the literature. We outline two distinct waste types: (i) obvious waste, to refer to any waste that can be reduced without creating another form of waste; and, (ii) buffer waste, to refer to any waste that cannot be reduced without creating another waste. The paper has important implications for practice. To reduce waste, managers must undertake three interlinked tasks: the elimination of obvious waste; the reduction of variability to transform buffers into obvious waste; and, the balancing of remaining buffers to best achieve performance targets. The paper supports managers in their endeavors to identify waste, which is an important precursor to waste reduction/elimination.
\end{abstract}

Keywords: Waste; Lean; Buffer; Systematic Literature Review. 


\section{Introduction}

The emergence and subsequent popularization of lean management has been one of the most significant developments in the history of the Operations Management discipline (e.g. Hines et al., 2004; Dennis, 2007; Holweg, 2007). Most scholars would agree that one of the main principles of lean is waste reduction (e.g. Bhamu \& Sangwan, 2014). But although waste is one of the most frequently used terms in the lean literature, it has been taken for granted that we have a common understanding of what the term means. In fact, a closer look at the literature demonstrates that there is a great deal of ambiguity concerning the term "waste" with different authors using the term differently; and with waste being conceptualized in various ways.

The seminal work of Ohno (1988) and Shingo (1989), for example, suggested seven waste categories: over-production, waiting, transportation, over-processing, inventory, unnecessary motion, and defects. Later, Shah \& Ward (2003, pp 137) identified two major forms of waste: work-in-process inventory and unnecessary delays in flow time. The authors' distinction however omits excess capacity as this does not cause delays in flow time waiting capacity is costly but speeds up the product flow. Shah \& Ward (2007) then later suggested that waste is "commonly held by firms as excess inventory or excess capacity (machine and human capacity) to ameliorate the effects of variability in supply, processing time, or demand (pp 791)". But this neglects other forms of capacity related wastes, such as over-processing and unnecessary motion. While excess capacity can be used to buffer the shop against fluctuations in demand, the latter two forms of waste are lost capacity. On the contrary, Hopp \& Spearman (2004) viewed excess inventory and capacity as being excess buffering - where buffering is not the same as waste since waste was defined by the authors as the source of excess buffering. Meanwhile, Narasimhan et al. (2006) differentiated between 'obvious' wastes, e.g. long set-up times, unreliable machines and rework, and 'less obvious' wastes associated with variability. The authors' work made reference to forms of waste not referred to in earlier studies, like unreliable machines. Unreliable machines were considered to be variability in previous work and thus a source of waste, i.e. a condition that leads to waste, rather than directly as being waste.

From the above brief discussion, it becomes clear that there is a plethora of different uses of the term "waste" in the literature. This becomes important because how waste is understood in a given study impacts what can be inferred from the results. Further, if waste is interpreted differently across studies, then this affects comparability and restricts the applicability of findings to practice. Yet although there have been many broad reviews on the 
lean paradigm (e.g. Hines et al., 2004; Papadopoulou \& Özbayrak, 2005; Holweg, 2007; Shah \& Ward, 2007; Moyano-Fuentes \& Sacristán-Díaz, 2012; Bhamu \& Sangwan, 2014; Jasti \& Kodali, 2015), to the best of our knowledge, a review specifically on waste has not been presented. This is a significant research gap as the lack of a coherent and consistent definition of waste undermines both our understanding of lean and its effectiveness. We therefore ask:

What are the waste 'concepts' that can be identified in the literature? And, can a consistent definition of waste be constructed that integrates these concepts?

In response to this research question, we combine a critical, qualitative discussion with a systematic review of the literature. The qualitative discussion is first used to identify the relevant waste concepts before the systematic review explores the use of these concepts in the literature. Building on these two steps, we then construct a new definition of waste that:

- Resolves ambiguity and inconsistencies concerning the definition of waste (and consequently lean); and

- Improves the utility of the waste concept for research and practice given that the first step to reducing or removing waste is being able to properly define/see it.

It is hoped that our review and definition lead to two major contributions. First, the various and dispersed waste concepts that can be found in the literature are integrated into one coherent waste framework. This is a major theoretical contribution since it enhances our understanding of the waste concept and consolidates the literature concerned with waste. Second, a coherent and comprehensive waste framework is provided, which forms the basis of an effective diagnosis tool for practice. This enhances a manager's ability to see waste, which is an important step towards waste reduction/elimination. Finally, although our study, and the literature it is based upon, has a skew towards manufacturing industries, it is argued to be of equal value to all kinds of product and service processes.

The remainder of this paper is organized as follows. The waste concepts to be included in our systematic review are identified in Section 2. Section 3 then presents the systematic review of the literature on the use of these concepts. An overall discussion of results is then provided in Section 4, leading to a new definition of the waste concept. Final conclusions are summarized in Section 5, where managerial implications and future research directions are also outlined. 


\section{Identifying Waste Concepts}

The overall structure of our research approach is summarized in Figure 1. This section presents a discussion of concepts used in lean management that are denoted by the term waste. The main objective is to identify the concepts that have to be considered in our systematic literature review. But first, the etymological meaning of the term waste is clarified in Section 2.1 before Section 2.2 focuses on identifying the relevant concepts. A summary is finally presented in Section 2.3.

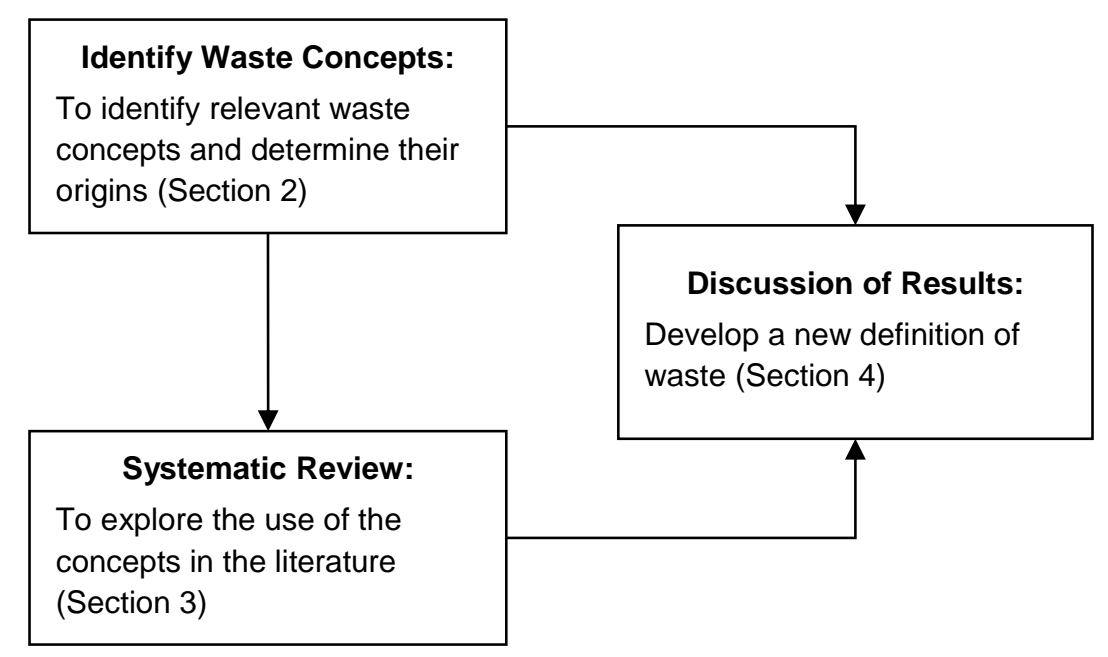

Figure 1: Summary of Research Approach

\subsection{Etymological Background}

\subsubsection{Waste - A Dictionary Definition}

In this study, we focus on waste as a noun since this is how it is typically used in the relevant literature, e.g. when saying that lean is about waste elimination. Following MerriamWebster's online dictionary definition, the noun 'waste' refers to:

"loss of something valuable that occurs because too much of it is being used or because it is being used in a way that is not necessary or effective; an action or use that results in the unnecessary loss of something valuable; a situation in which something valuable is not being used or is being used in a way that is not appropriate or effective."

Thus, in its etymological meaning, waste is something valuable - such as energy, material or time - that is lost, i.e. something that loses its value. This has two fundamental implications. First, that there must be some commodity that is valued. And, second, that waste is concerned with a loss in this valued commodity. Hence, reducing waste does not add 
value - it only maintains the current value of a commodity, stopping its erosion. Adding value implies the redeployment of saved resources. Reducing waste may free up capacity and reduce cost; however, whether freed capacity is used to add value to the product or whether cost savings are passed on to the customer in the form of lower prices is a managerial decision and independent of the reduction in waste.

\subsubsection{Muda, Mura, Muri}

The Japanese word muda is synonymous with waste. One of the first uses of this word in the English speaking Operation Management literature was by Schonberger (1982: pp 44) who stated that, among Japanese manufacturing people, 'Avoid muri, muda, mura' is regarded as a plea. Schonberger (1982) defined muda mainly in terms of a loss of quality. Meanwhile, the related mura and muri terms are defined as variability and excess (e.g. ordering too much from external suppliers), respectively. In the English translations of Ohno's (1988: pp 41) work, muda was translated directly as waste while mura and muri were translated into inconsistency and unreasonableness. Meanwhile, Harrison (1992: pp 267) defined mura as irregularity and muri as excessiveness. Thus, in the literature, muda is considered to be waste while mura and muri are considered to be sources of waste, i.e. conditions that lead to the creation of waste.

\subsection{Waste Concepts}

This section discusses the relevant waste concepts from the literature. Four concepts could be identified: the concept of the seven wastes (Section 2.2.1); waste as non-value adding activity (Section 2.2.2); obvious and less-obvious waste (Section 2.2.3); and, waste as buffers (Section 2.2.4).

\subsubsection{The Concept of Seven (or Eight) Wastes}

Ohno (1988) divided wastes into seven categories. Similarly, Shingo (1989) listed the same seven kinds of waste identified in the Toyota Production System. Table 1 provides definitions of each of the seven wastes from the two authors together with a more recent set of definitions presented by Liker (2003). 
Table 1: Definition of the Seven Wastes from the Literature

\begin{tabular}{|c|c|c|c|}
\hline The 7 Wastes & $\begin{array}{l}\text { According to Ohno } \\
\qquad(1988)\end{array}$ & According to Shingo (1989) & According to Liker (2003) \\
\hline $\begin{array}{l}\text { Over- } \\
\text { production }\end{array}$ & $\begin{array}{c}\text { Process transformation } \\
\text { without need e.g. to avoid } \\
\text { waiting. }\end{array}$ & $\begin{array}{c}\text { Part of operation. } \\
\text { Anticipated process } \\
\text { transformations; producing } \\
\text { too much. }\end{array}$ & $\begin{array}{l}\text { Producing items for which there } \\
\text { are no orders. }\end{array}$ \\
\hline Waiting & $\begin{array}{l}\text { Waste of time at hand. } \\
\text { Any delay in the actions } \\
\text { that accomplish process } \\
\text { transformation. }\end{array}$ & $\begin{array}{l}\text { Part of operations. Any } \\
\text { delay in the actions that } \\
\text { accomplish process } \\
\text { transformations. }\end{array}$ & $\begin{array}{l}\text { Workers merely serving to } \\
\text { watch an automated machine or } \\
\text { having to stand around waiting } \\
\text { for the next processing step, } \\
\text { tool, supply, part, etc., or just } \\
\text { plain having no work because of } \\
\text { stock-outs, lot processing } \\
\text { delays, equipment downtime, } \\
\text { and capacity bottlenecks. }\end{array}$ \\
\hline Transportation & $\begin{array}{l}\text { Waste of carrying. Any } \\
\text { movement of material or } \\
\text { products. }\end{array}$ & $\begin{array}{c}\text { Part of process. Any } \\
\text { movement of material or } \\
\text { products. }\end{array}$ & $\begin{array}{l}\text { Carrying work in process (WIP) } \\
\text { long distances, creating } \\
\text { inefficient transport, or moving } \\
\text { materials, parts, or finished } \\
\text { goods into or out of storage or } \\
\text { between processes. }\end{array}$ \\
\hline $\begin{array}{l}\text { Over- } \\
\text { processing }\end{array}$ & $\begin{array}{c}\text { Waste of processing } \\
\text { itself. Taking unneeded } \\
\text { steps to process the parts. }\end{array}$ & $\begin{array}{l}\text { Part of process. Producing } \\
\text { anything which is not } \\
\text { valued by the customer. } \\
\text { Value engineering and } \\
\text { value analysis must be } \\
\text { carried out first. Instead of } \\
\text { focusing merely on } \\
\text { efficiency, the question is } \\
\text { why we make a given } \\
\text { product and use a given } \\
\text { method. }\end{array}$ & $\begin{array}{l}\text { Taking unneeded steps to } \\
\text { process the parts. Inefficiently } \\
\text { processing due to poor tool and } \\
\text { product design, causing } \\
\text { unnecessary motion and } \\
\text { producing defects. Waste is } \\
\text { generated when providing } \\
\text { higher-quality products than is } \\
\text { necessary. }\end{array}$ \\
\hline Inventory & $\begin{array}{l}\text { Waste of stock at hand. } \\
\text { Work-in-Process and } \\
\text { Finished Goods Inventory }\end{array}$ & $\begin{array}{l}\text { Part of process. Work-in } \\
\text { Process (and related process } \\
\text { delays) and Finished Goods } \\
\text { Inventory }\end{array}$ & $\begin{array}{l}\text { Excess raw material, WIP, or } \\
\text { finished goods causing longer } \\
\text { lead times, obsolescence, } \\
\text { damaged goods, transportation } \\
\text { and storage costs, and delay. }\end{array}$ \\
\hline $\begin{array}{l}\text { Unnecessary } \\
\text { motion }\end{array}$ & $\begin{array}{l}\text { Waste of movement. Any } \\
\text { motion which does not } \\
\text { transform the product } \\
\text { adding value. }\end{array}$ & $\begin{array}{l}\text { Part of operations. Any } \\
\text { action which does not } \\
\text { transform the product } \\
\text { adding value. }\end{array}$ & $\begin{array}{l}\text { Any wasted motion employees } \\
\text { have to perform during the } \\
\text { course of their work, such as } \\
\text { looking for, reaching for, or } \\
\text { stacking parts, tools, etc. }\end{array}$ \\
\hline Defects & $\begin{array}{l}\text { Waste of making } \\
\text { defective products. }\end{array}$ & $\begin{array}{l}\text { Part of process. Any quality } \\
\text { loss, expressed as rework or } \\
\text { scrap. }\end{array}$ & $\begin{array}{l}\text { Production of defective parts or } \\
\text { correction. Repair or rework, } \\
\text { scrap, replacement production, } \\
\text { and inspection mean wasteful } \\
\text { handling, time, and effort. }\end{array}$ \\
\hline
\end{tabular}

It should be noted that Shingo's (1989) seven wastes only have meaning when creating the product/service is understood as being a two-dimensional functional network of process 
and operations: "Processes transform material into products. Operations are the actions that accomplish those transformations" (Shingo, 1989: pp 4). Shingo's (1989) two-dimensional network allows the seven classic wastes to be categorized as either process wastes (overprocessing, transportation, inventory, and quality defects) or operation wastes (overproduction, unnecessary motion, and waiting). The distinction between process and operation wastes reflects the basic distinction between inventory flow and operations flow. Both have to be co-ordinated. While this distinction may appear trivial, it is only by using these dimensions that we can distinguish between inventory waste (which is waiting inventory flow) and waiting waste (which is waiting operations flow).

While most of the definitions in Table 1 are very similar, there are significant differences between the three authors in terms of how over-processing waste is defined. First, in Ohno (1988), the definition of over-processing waste overlaps with that of unnecessary motion. Second, in Shingo (1989), over-processing is created before the transformation process takes place - thus it is a waste (inefficiency) related to the effectiveness of the process. Finally, Liker's (2003) definition is similar to Ohno's (1988) but refines it by putting extra emphasis on quality. Interesting is Liker's (2003) statement that products with higher-than-necessary quality should be regarded as waste. This suggests a balancing act with the waste of quality defects, rather than their total elimination if quality is understood as being about conformance to specification. If quality is understood as being about the specification itself, then it overlaps with Shingo's (1989) definition.

The definitions of the seven wastes summarized in Table 1 relate to system variables. Thus, contrary to Hines \& Rich (1997) - who argued for the adaptation of the seven wastes to particular industries and non-Japanese settings - they are acontextual, meaning product/service elements and cultural aspects are assumed to have no impact. For example, Bicheno \& Holweg (2008) argued for an adaptation of the seven wastes to meet service processes. They argued for using the terms delay, duplication, unnecessary movement, unclear communication, resource inefficiencies, opportunities lost to retain or win customers, and errors/mistakes. But it is argued here that these wastes largely reflect the 'classical' seven wastes; while unclear communication is a source of waste (equally applicable to manufacturing and services) and opportunities lost to retain or win customers is a possible consequence of waste (again equally applicable to manufacturing and services). Meanwhile, researchers and practitioners sometimes add a subjective human component, which is often referred to as the eighth waste. For example, Liker (2003) added 'unused employee creativity' as a further form of waste in addition to the original seven. While there is no doubt that 
humans are an integral part of production and service systems, employee creativity, e.g. in the form of process improvement, is often kept separate from the normal working of the system, e.g. in the form of quality circles.

Two conclusions can be drawn from this discussion. First, that the seven wastes are system variables and different from 'human' variables, like unused worker creativity or the waste of talent (e.g. Protzman et al., 2010), which are often introduced as additional forms of waste. And second, that the seven wastes - as system variables - can be determined according to their position in Shingo's (1989) two dimensional network used to describe the system. In fact, each of the classic seven wastes represents a symptom of inefficiency at some point in the system. In accordance with Shingo (1989), this may be either a production or service system.

\subsubsection{The Concept of Waste as Non-Value Adding Activity}

It should be noted that neither Ohno (1988) nor Shingo (1989) gave a definition of waste. Rather they presented the seven waste categories - as discussed in Section 2.2.1 above - and identified different aspects of the production system as being waste. We argue here that one of these aspects gave rise to the concept of waste as non-value adding activity. More specifically, Ohno (1988: pp 57) stated: "Through close observation, we can divide the movement of workers into waste and work:

- Waste - the needless, repetitious movement that must be eliminated immediately. For example waiting for or stacking subassemblies.

- Work - The two types are non-value-added work and value added work.

Non-value-added work may be regarded as waste in the conventional sense.... Value added work means some kind of processing - changing the shape or character of a product or assembly." Similarly, Shingo (1989) argued that there are two types of operations: those that add value and those that do not - with the former being operations that actually transform materials, changing either their form or quality. The three categories of movement identified by Ohno (1988) have been interpreted as non-value adding (or pure waste), necessary nonvalue adding, and value adding activities (e.g. Hines \& Rich 1997; Browning, 2003; Sahoo et $a l ., 2008)$. This definition raises the question as to what exactly constitutes value?

Both Ohno (1988) and Shingo (1989) referred to the efficiency of operations when defining value. In fact, Ohno (1988: pp 58) even explained that improving the ratio between value and non-value adding work was his greatest concern whilst developing the Toyota Production System. So both authors and their views on value adding and non-value adding 
work paraphrase how efficiency is typically expressed: as the ratio between a certain quantity of some valuable output produced and a certain quantity of some valuable resource consumed.

The view of value shifted significantly after the publication of Womack \& Jones (1996). Hines et al. (2004: pp 996) wrote: “In 1996, Womack and Jones crystallised value as the first principle of lean thinking (Womack and Jones, 1996). As such, lean had moved away from a merely "shop-floor-focus" on waste and cost reduction, to an approach that contingently sought to enhance value (or perceived value) to customers by adding product or service features and/or removing wasteful activities. This was a key development, as value was linked to customer requirements, and no longer was simply define through its opposite, waste, on the shop-floor." This suggests that two value propositions exist in the lean literature with different impacts on the concept of waste:

i. Value defined by system input and system output, where any loss in value during the transformation process (inefficiency) is considered to be waste (from Ohno, 1988; Shingo, 1989).

ii. Value defined by product/service characteristics (from Womack \& Jones, 1996). Adding features of services that are not valued by the customer leads to over-processing waste in Shingo's (1989) sense. Shingo's (1989) main objective was increasing efficiencies during the transformation process; thus, adding product features to create competitive advantage was beyond the scope of his considerations.

\subsubsection{The Concept of Obvious and Less Obvious Waste}

A third subdivision of waste was suggested by Narasimhan et al. (2006 pp 441-442) who stated that: "Recent studies (Hopp and Spearman, 2004; de Treville and Antonakis, 2006) identify modes of waste reduction including “obvious wastes"' such as unneeded processes, excessive setup times, unreliable machines, rework, and the "less obvious" wastes associated with variability. (p. 441-442). This subdivision requires closer scrutiny since it is difficult to understand why unreliable machines - which are typically associated with variability - are obvious waste and not less-obvious waste. We assume that the authors took their definition from Hopp \& Spearman (2004) because de Treville \& Antonakis (2006: pp 101) simply stated that: “any slack in the system is referred to as 'waste' (e.g., Womack et al., 1990)". Hopp \& Spearman (2004 pp 144-145) wrote: "Obvious waste is the first source of excess buffering. Such waste includes operations that are not needed, excessive setup times, unreliable machines that can be made more reliable, rework that can be eliminated, etc." Thus, Hopp \& Spearman (2004) referred to 'unreliable machines that can be made more 
reliable', which is quite different from 'unreliable machines'. The former expression suggests that there is a potential capacity loss while the latter just refers to uncertainty. This difference is best captured by the concept of assignable causes (variability) and common causes (variability), as used by Shewart (1931) and Deming (1982) among others. An unreliable machine that can be made more reliable is a machine subject to assignable causes. The unreliability that is due to assignable causes is a form of obvious waste. Meanwhile, the term/concept of less-obvious waste cannot be identified in Hopp \& Spearman (2004).

Hopp \& Spearman (2004) also did not define what they understood by obvious waste, although they did list some examples. So our key is their understanding of excess buffering. Since waste is a source of excess buffering, we at least gain an understanding as to what waste is not. Buffers were defined by Hopp \& Spearman (2004) in terms of excess inventory (safety stocks), excess capacity and safety lead time. However, the important question is how excess buffering is defined - the only possibility appears to be the degree of risk that a manager is willing to take, which subdivides inventory, capacity and lead time into a portion that is for buffering/safety and a portion that is excessive. However, no such suggestion is explicitly made by Hopp \& Spearman (2004). The subdivision of buffer/excess buffer and waste/obvious waste is also suggested by Hopp \& Spearman's (2004 pp146) statement that: "Because variability necessitates buffering, it is a fundamental source of waste."

To be the source of each other, waste/obvious waste and buffering/excess buffering must be different. So - in our understanding - Hopp \& Spearman (2004) would not consider excess inventory or excess capacity to be waste. But it is not clear as to what exactly is gained from this that we cannot already learn from the original seven wastes, which would denote both excess inventory and excess capacity as waste (of inventory and waiting, respectively).

From the above, it can be concluded that the concept of obvious and less-obvious waste is less than obvious. Moreover, it remains unclear what the major contribution of this stream of literature is compared to the original concept of seven wastes put forward by Ohno (1988) and Shingo (1989).

\subsubsection{Waste as Buffers}

While, for Hopp \& Spearman (2004), waste is different from buffering, for other authors waste is equal to buffering. Shah \& Ward (2007) argued that waste is: commonly held by firms as excess inventory or excess capacity (machine and human capacity) to ameliorate the effects of variability in supply, processing time, or demand ( $p$ p 791)". Another possible 
difference is the notion of a conscious act of 'holding' a buffer/waste, which is different from the notion of a buffer as necessarily manifesting itself as in Hopp \& Spearman (2004).

However, there is a question concerning how Shah \& Ward (2007) define capacity since they go on to state that, according to Little's law, inventory in a system can be reduced by either maintaining extra capacity or lowering throughput time. To the best of our knowledge, Little's Law refers to throughput rate and not to capacity. Moreover, to the best of our knowledge, throughput times cannot be lowered directly but are a result of the throughput rate and inventory in the system. It should be noted that Shah \& Ward (2003, pp137) defined waste in terms of work-in-process (WIP) inventory and unnecessary delays in flow time. However, unnecessary delays in flow time tend to create work-in-process and vice versa, which makes it difficult to separate out these waste types. Shah \& Ward (2007) recognized this, but still their definition of excess capacity remains unclear.

Viewing waste simply as being excess inventory and excess capacity reduces the seven wastes to the two dimensions of Shingo's functional network. For example, in our understanding, excess capacity may be any of the operational wastes using Shingo's framework of seven wastes (waiting, over-processing, or unnecessary motion). Thus, it remains unclear how this stream of work improves our understanding of waste, since it just represents a more general category. While there is no doubt that excess capacity is an important waste/buffer, it is argued here that a more granular and precise categorization is needed. Moreover, this approach to conceptualizing waste overlooks important inefficiencies (e.g. defects) that are captured by the seven wastes.

\subsection{Summary}

This section has identified four concepts that are denoted by the term waste:

i. The Concept of Seven (or Eight) Wastes: The seven wastes can be considered symptoms of inefficiencies differentiated according to their place in the system. They are different to other wastes often presented in the literature - such as 'unused employee creativity' since they are independent of what is produced (or served in the process) and of cultural aspects.

ii. The Concept of Waste as Non-Value Adding Activity: There are two types of value that have been identified in this stream of literature. One related to efficiencies and one related to enhancing product or service features. Waste directly relates to the first type, while the second type would relate to inefficiencies created by adding product/service features that are not valued by the customer. 
iii.The Concept of Obvious and Less Obvious Waste: Obvious waste is a source of excess buffering; and buffering is a source of waste. But no clear criterion to differentiate between waste/obvious waste and buffering/excess buffering is presented. Buffers are excess inventory, excess capacity and safety lead time; and thus they are considered different from waste. It remains unclear from the literature what is gained by this concept compared to concepts (i) and (ii) above.

iv. The Concept of Waste as Buffers: Waste is defined as any additional capacity or inventory. Waste categories that were considered not to be waste under (iii) are now considered to be waste. Again, the question remains what is gained compared to (i) and (ii) above? If anything, meaning appears to be lost. For example, important aspects as quality defects are neglected here.

A systematic review will now be applied to explore the use of these concepts in the literature.

\section{Systematic Review - The Use of Waste Concepts in the Literature}

\subsection{Systematic Literature Review - Methodology}

A systematic procedure for retrieving and selecting the articles for our review of the use of the identified waste concepts in the literature has been applied, following Tranfield et al. (2003). The three subsections below outline the approach adopted for sourcing, screening and analyzing the articles (subsections 3.1.1 to 3.1.3) before the sample characteristics are summarized in Section 3.1.4. Meanwhile the overall scheme is illustrated in Figure 2. The results of our review will then be presented in Section 3.2. 
Sourcing the Articles

Data is retrieved from Scopus

1,763 Articles
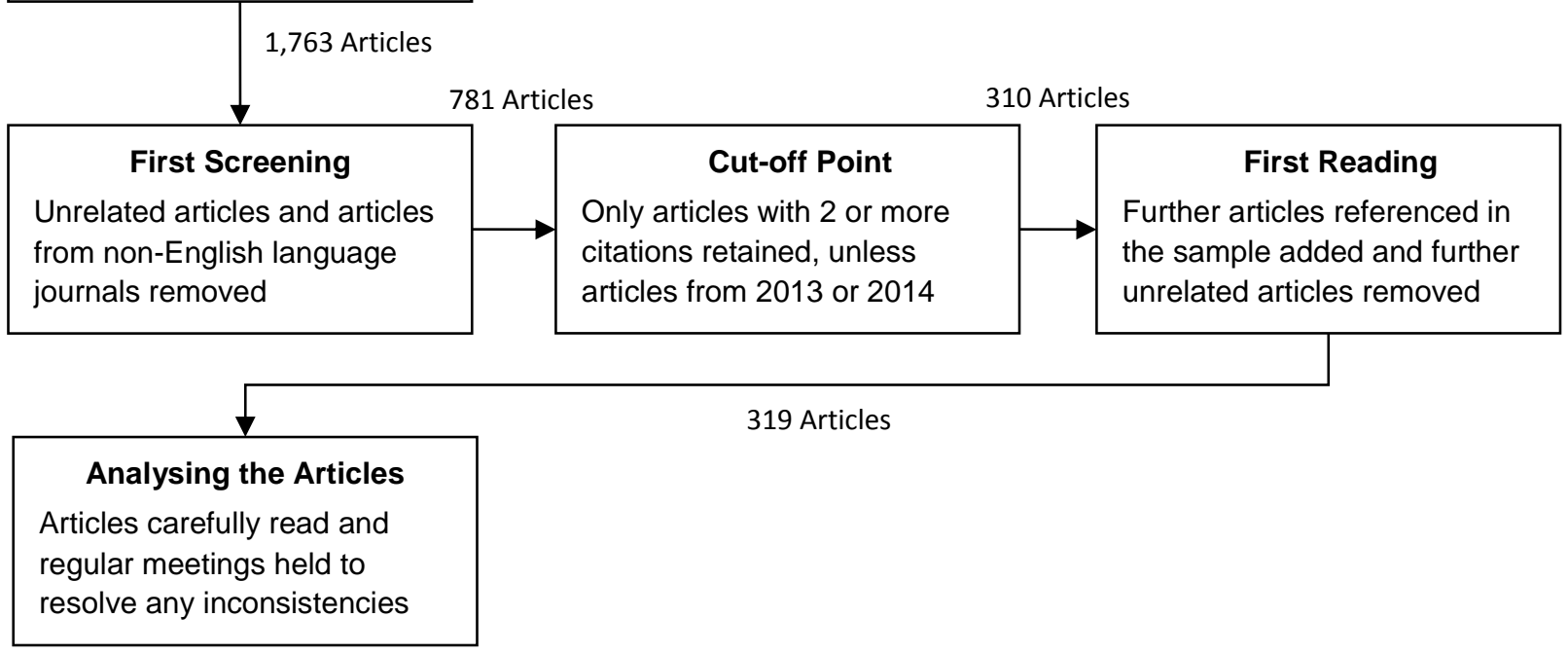

Figure 2: Systematic Review of the Literature: Methodology

\subsubsection{Sourcing the Articles}

The bibliographic database used for sourcing the articles was Scopus - due to its large coverage, e.g. compared to Web of Science, and its accuracy in terms of citation counts, e.g. compared to Google Scholar. We recognize that there is an extensive literature in the form of books and white papers. However, it was not possible for us to have access to all relevant books for a systematic review, while we restricted articles to peer-reviewed journals to keep the number of articles reasonable and ensure the quality of the sources held in our database. Scopus was queried in December 2014 using the term "waste" in combination with concepts and streams of literature with which it is associated. To keep our results to a reasonable number, we restricted our search to the title, abstract and keywords of papers. There was no restriction on the year of publication.

We retrieved for "waste" together with "lean", 650 entries; "lean manufacturing", 216 entries; "lean production", 125 entries; "Toyota Production System", 44 entries; "TPS”, 34 entries; "Just-In-Time”, 151 entries; “JIT", 95 entries; “Total Quality Management”, 96 entries; "TQM", 30 entries; and "Six Sigma", 74 entries. We also searched for the keywords "muda", "mura" and "muri", which yielded 23, 201 and 24 entries, respectively. In total, this process retrieved 1,763 articles.

\subsubsection{Screening the Articles}

The original sample of 1,763 articles was reduced to 1,141 by removing duplicates. This was 
further reduced to 832 articles by excluding apparently unrelated articles, mostly about material sciences, and to 781 by excluding journals that are not published in English language. The sample obtained for muda, mura and muri contained mostly unrelated articles. For example, muda also stands for Multiple Unit Double Action; Mura is a river running through central Europe (Austria, among other countries), and a term often mentioned in the material sciences literature, e.g. on soldering, cracks in materials, etc.; and, muri also stands for Multi University Research Initiative. In fact, only 11 papers were added to our sample from the searches for muda, mura and muri.

The sample of 781 articles was further reduced based on citation counts. We decided to limit our final sample to papers that had been cited 3 times or more, with the cut-off point of 3 citations set arbitrarily. Thus, all articles with 2 or less citations were removed from the sample, leaving 285 articles. Since this cut-off point would be unfair for recently published articles, we included articles with 2 or less citations if they were published in 2013 or 2014. This added another 133 articles to our review. The sample therefore consisted of 418 articles. Using several channels for retrieving the full articles, a total of 310 articles could be obtained.

To ensure that we did not miss relevant articles, we further cross-checked the references used for the term waste in the 310 articles and, from this process, retrieved a further 21 relevant articles. This approach of supplementing the set of articles that had been mechanically retrieved ensured that the list of articles was complete, but the number of articles added (21) was not so great to suggest that the original search process was inadequate. During this article retrieval and screening process, we discovered that a further 12 articles in the sample were not in fact sufficiently related to our study. The final sample of analyzed full papers was thus $310+21-12=319$ articles.

Finally, note that only the articles that are referred to directly in our review (or tables) are listed at the end of this paper, but a full reference list of all 319 articles is available from the corresponding author upon request.

\subsubsection{Analyzing the Articles}

This stage involved extracting and documenting information from each of the 319 sources. To minimize subjectivity, the authors: (i) cross-checked results; and, (ii) conducted regular meetings to resolve any emerging inconsistencies in interpreting the results. Our major research vehicle was content analysis, since we sought to explore the meaning of the term waste in the literature. Our analysis focused on two main aspects, with the results presented in the next section: 
i. The given definition of waste (if any); and

ii. The use of the term waste in the text - since it is this context of use that allows meaning to be distilled from texts (Krippendorff, 2003).

As a template for data collection, a simple matrix was used where, for each paper (row), we asked (column): What is the formal definition of waste? What is the context of use (i.e. what is it used for)? What would be its definition out of its context of use? And, with which concept is it used (Lean, Total Quality Management, etc.)? Before presenting the results of this analysis process, Section 3.1.4 summarizes the basic sample characteristics.

\subsubsection{Sample Characteristics}

Basic sample characteristics for the 319 articles are summarized in Table 2, 3 and 4. Table 2 presents the distribution of journals where the articles have been published. This demonstrates that our sample contains a broad set of different journals. As expected, leading Operations Management journals feature heavily in Table 2. This supports the claim that the review is representative of the literature. Table 3 presents the distribution of the main management concepts relating to lean while Table 4 summarizes the areas of application. As expected, most articles relate to lean and to manufacturing. However, while there is a heavy bias towards manufacturing, we argue that the results are also of interest to service systems. The broad set of management concepts and areas of application provide further support for the representativeness of our sample. 
Table 2: Sample Characteristics - Journals Where Relevant Papers Have Been Published

\begin{tabular}{ll}
\hline Journal & Number of Articles (Percent) \\
\hline International Journal of Production Research & $25(7.84 \%)$ \\
Production Planning and Control & $13(4.08 \%)$ \\
International Journal of Advanced Manufacturing Technology & $11(3.45 \%)$ \\
Journal of Operations Management & $10(3.13 \%)$ \\
Journal of Cleaner Production & $9(2.82 \%)$ \\
International Journal of Production Economics & $8(2.51 \%)$ \\
International Journal of Productivity and Performance Management & $7(2.19 \%)$ \\
Construction Management and Economics & $6(1.88 \%)$ \\
Journal of Manufacturing Technology Management & $6(1.88 \%)$ \\
International Journal of Quality and Reliability Management & $6(1.88 \%)$ \\
Manufacturing Engineer & $5(1.57 \%)$ \\
Total Quality Management and Business Excellence & $5(1.57 \%)$ \\
Journal of Construction Engineering and Management & $5(1.57 \%)$ \\
TQM Magazine & $4(1.25 \%)$ \\
Assembly Automation & $4(1.25 \%)$ \\
Building Research and Information & $4(1.25 \%)$ \\
Supply Chain Management & $4(1.25 \%)$ \\
International Journal of Operations and Production Management & $4(1.25 \%)$ \\
Architectural Engineering and Design Management & $4(1.25 \%)$ \\
Automation in Construction & $3(0.94 \%)$ \\
Production Engineering & $3(0.94 \%)$ \\
Production and Operations Management & $3(0.94 \%)$ \\
Business Process Management Journal & $3(0.94 \%)$ \\
International Journal of Industrial Engineering and Management & $3(0.94 \%)$ \\
Quality and Reliability Engineering International & $3(0.94 \%)$ \\
\hline Others (two papers per journal) & $54(16.93 \%)$ \\
Others (one paper per journal) & $107(33.54 \%)$ \\
\hline Total & $\mathbf{3 1 9}(\mathbf{1 0 0 \%})$ \\
\hline & \\
\hline
\end{tabular}


Table 3: Sample Characteristics - Related Management Concepts

\begin{tabular}{ll}
\hline Related Management Concept & Number of Articles (Percent) \\
\hline Lean & $139(43.57 \%)$ \\
Just-In-Time (JIT) & $39(12.23 \%)$ \\
Lean Construction & $23(7.21 \%)$ \\
Lean Six Sigma & $20(6.27 \%)$ \\
Six Sigma & $10(3.13 \%)$ \\
Lean, Toyota Production System & $9(2.82 \%)$ \\
Lean, Environmental Management & $9(2.82 \%)$ \\
TPS & $8(2.51 \%)$ \\
Lean Health-Care & $7(2.19 \%)$ \\
Total Quality Management (TQM) & $6(1.88 \%)$ \\
Environmental Management & $5(1.57 \%)$ \\
Lean Product Development & $4(1.25 \%)$ \\
Total Productive Maintenance (TPM) & $4(1.25 \%)$ \\
Lean IT & $4(1.25 \%)$ \\
Lean, TQM & $4(1.25 \%)$ \\
Lean, Supply Chain Management & $4(1.25 \%)$ \\
Supply Chain Management & $3(0.94 \%)$ \\
\hline Other (no specific concept) & $8(2.51 \%)$ \\
Other (two papers) & $6(1.88 \%)$ \\
Other (one paper) & $7(2.19 \%)$ \\
\hline Total & $\mathbf{3 1 9 ( 1 0 0 \% )}$ \\
\hline
\end{tabular}

Table 4: Sample Characteristics - Areas of Application

\begin{tabular}{ll}
\hline Area of Application & Number of Articles (Percent) \\
\hline Manufacturing & $174(54.55 \%)$ \\
Construction & $33(10.34 \%)$ \\
Supply chain & $24(7.52 \%)$ \\
General & $24(7.52 \%)$ \\
Services & $15(4.7 \%)$ \\
Process industry & $10(3.13 \%)$ \\
Health-care & $9(2.82 \%)$ \\
Information technologies & $6(1.88 \%)$ \\
Aerospace and Defence & $5(1.57 \%)$ \\
Textile industry & $4(1.25 \%)$ \\
Education & $4(1.25 \%)$ \\
Food industry & $4(1.25 \%)$ \\
Public sector & $3(0.94 \%)$ \\
Waste management & $3(0.94 \%)$ \\
Government & $1(0.31 \%)$ \\
\hline Total & $\mathbf{3 1 9}(\mathbf{1 0 0 \%})$ \\
\hline
\end{tabular}


Meanwhile, the distribution of the articles by year of publication is shown in Figure 3. This shows a general trend of an increase in the total number of publications year-on-year and a jump for 2013 and 2014 (when the minimum citation count of 3 was not enforced). The results for 2015 refer to papers that were online when our database was established (December, 2014) but yet to be printed. Finally, our analysis showed that in terms of the research method applied in the studies, 85 articles were mainly conceptual, 172 had an empirical component and 62 were analytical. Other measures, like the distribution of articles per country, author profiles, etc. did not appear relevant to us and are thus not presented here.

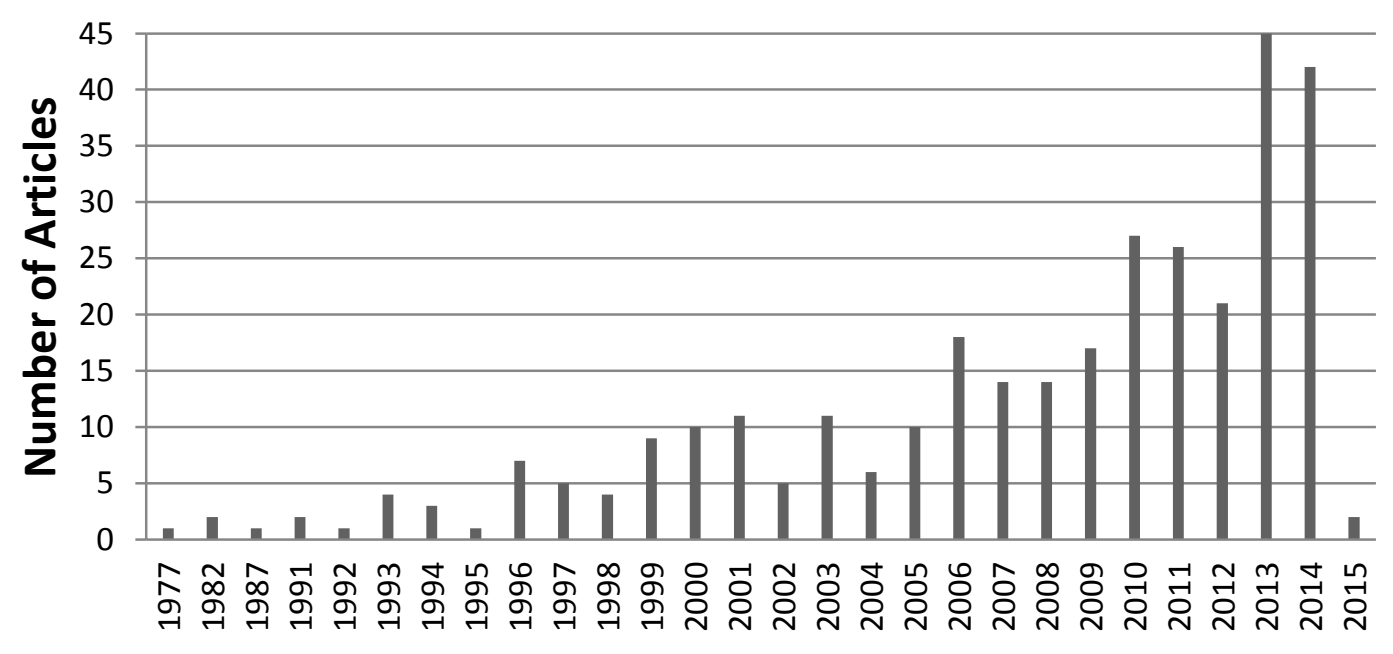

Year of Publication

Figure 3: Sample Characteristics - Distribution of Articles per Year

\subsection{Results of the Systematic Literature Review}

From the 319 articles in our final sample, 190 articles (60\%) gave no formal definition of waste; and no specific meaning for the term could be obtained from the context of its use in these articles. This suggests that the majority of authors assume waste to be a clear, wellunderstood and commonly applied concept that requires no further explanation. Most of these articles simply state that waste reduction is a principle of lean/JIT/Six Sigma etc. or very important for improving performance. Meanwhile, 9 articles (2.8\%) defined waste as pollution, e.g. as part of a lean-green initiative. The remainder of this section now focuses on drawing conclusions from the 120 articles that did provide a definition of waste.

\subsubsection{The Concept of Seven (or Eight) Wastes}

Of the 120 articles that provide a definition of waste, a definition based entirely on enumeration (e.g. the seven wastes) was given in 51 articles (16\% of 319). But most of these 
articles simply list the seven wastes without defining each waste category. Thus, it remains unclear how each category is defined, e.g. whether subtle differences were introduced, as in Liker (2003), or whether the authors remained faithful to the definitions in Ohno (1988) and/or Shingo (1989).

\subsubsection{The Concept of Waste as Non-Value Adding Activity}

A total of 58 articles (18\%) defined waste based on value (including 20 articles that also use the seven wastes concept). We do not explicitly cite all the definition here due to space restrictions, but a full list of all 58 definitions is available from the corresponding author upon request. The following could be observed from these definitions:

- In general, there are two kinds of definition: those which state any use of Variable X (e.g. an activity or anything else that adds costs) that does not create value is waste; and those which state anything that does not create value is waste (e.g. Akinc, 1993; Poppendieck \& Cusumano, 2012; Tserng et al., 2013). It is apparent that only the former set of definitions are meaningful, since they refer to a restricted set of variables that are used. Meanwhile, "anything" refers to an infinite and unspecified set of variables. Even stating anything that adds costs causes problems as it still would make machines, workers, etc. waste. We therefore propose a definition along the lines that waste refers to anything in the system that is used to create value but does not create value. It should be noted that, in our understanding, activities such as inspection, maintenance, etc can add value to the actual product experienced by the customer since they, for example, increase perceived quality. Our emphasis is on 'perceived' quality since inspection does not increase the quality of products; it only ensures that no defect products are delivered to the customer. It is only if they do not increase value anymore - e.g. since a poka-yoke is in place - that they become waste. Meanwhile, a lunch break would be classed as waste if we were to define waste as anything that does not create value or anything that adds cost. But a lunch break does not seek to add value to the output of an operation so it can never be considered waste according to our definition.

- Most definitions (29) refer to non-value adding activities (e.g. Oliver et al. 2007; Bortolotti \& Romano, 2012; Chongwatpol \& Sharda, 2013). This reflects Ohno (1988) and Shingo (1989) who denoted operations that do not add value as waste. However, it is apparent that waste definitions based only on non-value adding activities neglect wastes that relate to the process dimension, such as inventory. This leads to inconsistencies if waste is defined as seven wastes and non-value added (e.g. Hines \& Rich, 1997; 
Rawabdeh, 2005; Ramesh \& Kodali, 2012; Liu et al., 2013) ; or if the wastes used are not from the operation dimension, i.e. refer to the process (e.g. Arbos, 2002; Arbos et al., 2011; Bortolotti \& Romano, 2012).

- Some definitions speak about value as perceived by the customer (Arbulu et al., 2003; Eswaramoorthi et al., 2011; Arumugan et al., 2012; Zhou, 2012); value for the (end) customer (Dahlgaard \& Dahlgaard, 2002; Gorman et al., 2009, Petersen \& Wohlin, 2010; Dart, 2011); value to the product (e.g. Pheng \& Hui, 1999; Canel et al., 2000; Ramesh \& Kodali, 2012); or, value that the customer is willing to pay for (Oliver et al., 2007; Radnor, 2010). It is clear that the value for a customer (which is the totality of the product/service) differs both from what the customer perceives as value, which is a subset of product/service features, and what the customer is actually willing to pay for, e.g. the customer may not be willing to pay for value although he/she perceives it as value. This is at the bottom of, e.g. Hill's (1993) distinction between order-qualifiers and order-winners and Kano analysis (e.g. Shiba \& Walden 2001).

The above demonstrates that there is disparity in the conceptualization of waste as nonvalue-adding activity. Moreover, many definitions are not valid statements or lead to inconsistencies with either other definitions or with the waste category actually being used. While differences may appear small, they significantly affect the set of occurrences subsumed under a certain waste category. Thus, they significantly affect any scientific treatment of the waste concept. For example, the results in one study cannot be validly compared with those from another study.

\subsubsection{Other Definitions of Waste}

A total of 11 articles $(3.5 \%)$ defined waste without referring to value (or non-value adding) activity. These definitions - as summarized in Table 5 - include:

- Analytical papers that simply summarize all wastes under one measure (Li \& O’Brien, 1999; Lapré et al., 2000). But it is more than questionable how far one specific measure can accurately represent the whole complexity of the waste concept.

- Waste as being anything that interferes with the smooth flow of production (see Wee \& Wu 2009; Karim \& Arif-Uz-Zaman 2013). Both of these articles refer to a working paper by MacDuffie \& Helper (1997). This definition appears interesting at first sight, including elements of the theory of swift and even flow (Schmenner \& Swink, 1998). However, 
following this definition, high levels of inventory would not be considered to be waste thus, it remains questionable.

- Waste as any slack in the system (de Treville \& Antonakis, 2006), which partly overlaps with Tomasević \& Slović (2013) if slack were seen as a deviation from the optimum. However, besides the question of how slack is defined, we also need to ask what slack refers to - inventory, capacity, etc?

Table 5: Other Definitions of Waste (i.e. with no reference to value- or non-value-adding activities)

\begin{tabular}{|c|c|}
\hline Article & Waste Definition \\
\hline Li \& O'Brien (1999) & $\begin{array}{l}\text { Waste elimination is indicated by the gap between the SC desired stock cost } \\
\text { (zero) and the expected stock cost. (p148) }\end{array}$ \\
\hline Lim et al. (1999) & $\begin{array}{l}\text { The term waste is described in the Webster's English dictionary as produced } \\
\text { in excess. However, Shingo (1989), tackling the issue from a practitioner's } \\
\text { point of view, defines waste in terms of seven categories:.. (p304) }\end{array}$ \\
\hline Lapré et al. (2000) & $\begin{array}{l}\ldots \text { waste rate (measured by the ratio of wasted material to total material } \\
\text { released to the process). (p598) }\end{array}$ \\
\hline de Treville \& Antonakis (2006) & $\begin{array}{l}\text {...; any slack in the system is referred to as "waste" (e.g., Womack et al } \\
1990) .(p \text { 101) }\end{array}$ \\
\hline Wee \& Wu (2009) & $\begin{array}{l}\text { "Waste" is defined as anything that interferes with the smooth flow of } \\
\text { production (Macduffie \& Helper, 1997). (p336) }\end{array}$ \\
\hline Wang et al. (2011) & $\begin{array}{l}\text {...of issues that negatively impact on the performance indicators of product } \\
\text { quality, product cost, development time, development cost, and production } \\
\text { capability. This negative impact on the development in Toyota PD system is } \\
\text { called waste. (p7) }\end{array}$ \\
\hline Gudem et al. (2013) & $\begin{array}{l}\text { In product development, waste is typically associated with doing activities } \\
\text { with the wrong input rather than doing unnecessary activities, as is the case } \\
\text { in manufacturing. ( } \mathrm{p} 73 \text { ) }\end{array}$ \\
\hline Jainury et al. (2013) & $\begin{array}{l}\text {..., three types of waste should be eliminated; mura, muri and muda. } \\
\text { (p3682) }\end{array}$ \\
\hline Karim \& Arif-Uz-Zaman (2013) & $\begin{array}{l}\text { Waste is defined as anything that interferes with the smooth flow of } \\
\text { production (MacDufile and Helper, 1997). (p171) }\end{array}$ \\
\hline Maslaric et al. (2013) & $\begin{array}{l}\text { The main goal of lean production is to eliminate waste (the word 'lean' } \\
\text { means 'capable of operating without waste'), which is anything other than } \\
\text { minimum amount of equipment, materials, parts, and working time that are } \\
\text { absolutely essential to production. (p230) }\end{array}$ \\
\hline Tomašević \& Slović (2013) & $\begin{array}{l}\text { Wasteful activity is an exception that deviates process from optimal } \\
\text { execution. (p199) }\end{array}$ \\
\hline
\end{tabular}

Interestingly, no papers could be identified in the sample that explicitly defined waste using the concept of obvious and less-obvious waste or the concept of waste as buffers.

\section{Discussion of Results - Definition of Waste}

Our earlier discussion in Section 2 identified four waste conceptualizations: (i) the concept of seven wastes; (ii) the concept of waste as non-value adding activity; (iii) the concept of obvious and less-obvious waste; and, (iv) the concept of waste as buffers. We questioned 
what concepts (iii) and (iv) added and indeed our systematic review of the literature revealed that only concept (i) and concept (ii) are widely used. Thus, despite the recent attempt to redefine what waste is through concept (iii) and concept (iv), the dominant concepts relate to the seven wastes and non-value adding activity. One reason for the apparent failure to redefine waste appears to be that their proponents contradict each other. For example, while excess capacity and excess inventory are waste for Shah \& Ward (2007), they are buffers (and thus not waste) for Hopp \& Spearman (2004). Moreover, it remains unclear what is to be gained from this redefinition, which appears to be largely a subset of the original seven wastes (inventory and waiting). But there is much ambiguity even within concept (i) and (ii). For example, the seven waste categories are rarely defined and definitions based on the concept of non-value adding activity differ widely in their meaning.

This has important implications for lean literature and practice. The apparent congruence in our understanding of lean is only superficial. We all generally agree that one of the main principles of lean is waste reduction, but clearly there are fundamental problems with this, i.e. there is huge disparity in terms of what we all understand by the term waste. Without a clear understanding of what waste means, any definition of lean is undermined.

Building on the above, we will now construct a new definition of waste that it is hoped will resolve the prevailing ambiguity and inconsistency.

\subsection{Defining the Waste Concept}

Shah \& Ward (2007) started their widely cited article on defining lean with a quote from Plato, who suggested that linguistic confusion arises because multiple terms may refer to the same object or idea, a single term may refer ambiguously to more than one object or idea, and that terms may be confusing because they are out of date. The reference to Plato suggests that there is a 'truth' or 'reality' to lean - the ideal lean - and that our common sense impressions are imperfect copies of this reality. We want to start the construction of our definition by quoting Antisthenes: 'I can see horses, Plato, but I nowhere see your ideal horse' (following Feyerabend, 2010: pp 228). Similarly, we don't believe there is an ideal or a true waste. Neither Ohno (1988) nor Shingo (1989) positively defined waste - rather, they followed Spinoza's 'Omnis determinatio est negatio' and defined waste in terms of what it is not.

In our understanding, there are two key aspects that must be represented in a definition of waste: 
1. That waste is any system input (in terms of transforming and transformed resources) that is not transformed into an output that is valued by customers (fulfilled customer demand, this is neither unfulfilled nor exceeded), i.e. waste = system input - system output; and

2. That waste is any output or transformation that does not occur just-in-time, i.e. when customer demand is present.

Therefore, our general definition of waste is as follows:

Any system input (transformed resources, transforming resources) that is not transformed into a system output that is valued by customers (fulfilled customer demand, this is neither unfulfilled nor exceeded) just-in-time.

This definition highlights an important point for lean management. A system without any waste is an ideal system - in Weber's (2014), not Plato's sense of the ideal system - in which transformed resources, transforming resources and customer demand meet at the right time, in the right place, in the right quantity, and at the right level of quality. But such a system is unlikely to exist in reality - if there is variability (in supply, demand, quality, etc.) then there will always be some form of waste. And some level of variability is inevitable. Therefore, we will further define two waste types based on their dependence on variability:

\footnotetext{
Type I Waste (Obvious waste): Any waste that can be reduced without creating another form of waste is obvious waste.

Type II Waste (Buffer waste): Any waste that cannot be reduced without creating another waste is a buffer.
}

An example of an obvious waste is the needless, repetitive movement of personnel due to poor shop layout or job design, as mentioned in Ohno (1988). It is based on concepts such as Hopp \& Spearman's (2004) 'obvious waste' and Liker \& Meier's (2006) 'big waste'. Meanwhile, the reference to buffers above draws on Hopp \& Spearman's (2004: pp 145) argument that when variability exists, it will be buffered somehow. Reducing a waste that is due to variability without reducing variability itself will only lead to the creation of another form of waste, perhaps at another point in the system. Thus, our waste framework integrates the dispersed waste concepts from the literature. It integrates the obvious waste and buffer concepts put forward by Hopp \& Spearman (2004) and by Shah \& Ward (2007) into our waste definition, but in a form that clarifies its relationship with the pre-existing waste concepts of the seven (or eight) wastes and waste as non-value adding activity. We argue that 
the distinction between buffer and obvious waste applies to any waste and not just a restricted set, as suggested by Hopp \& Spearman (2004) and Shah \& Ward (2007), e.g. inventory and waiting. In our opinion, each waste category (such as the seven wastes, which are differentiated according to their position in the system) has two waste types (determined by variability), i.e. obvious waste and buffer waste. This extends the two-dimensional network proposed by Shingo (1989), as illustrated in Figure 4. The original network was made up of the process and operation dimensions, with the seven classic wastes categorized as either process wastes or operation wastes. Our work adds a third dimension to this network made up of buffer and obvious wastes, which is referred to as the waste type dimension. Building on this, the objective of management can now be stated as:

- To eliminate obvious waste;

- To reduce variability, transforming buffers into obvious waste; and

- To balance or swap (Hopp \& Spearman, 2004) buffers to best achieve performance targets.

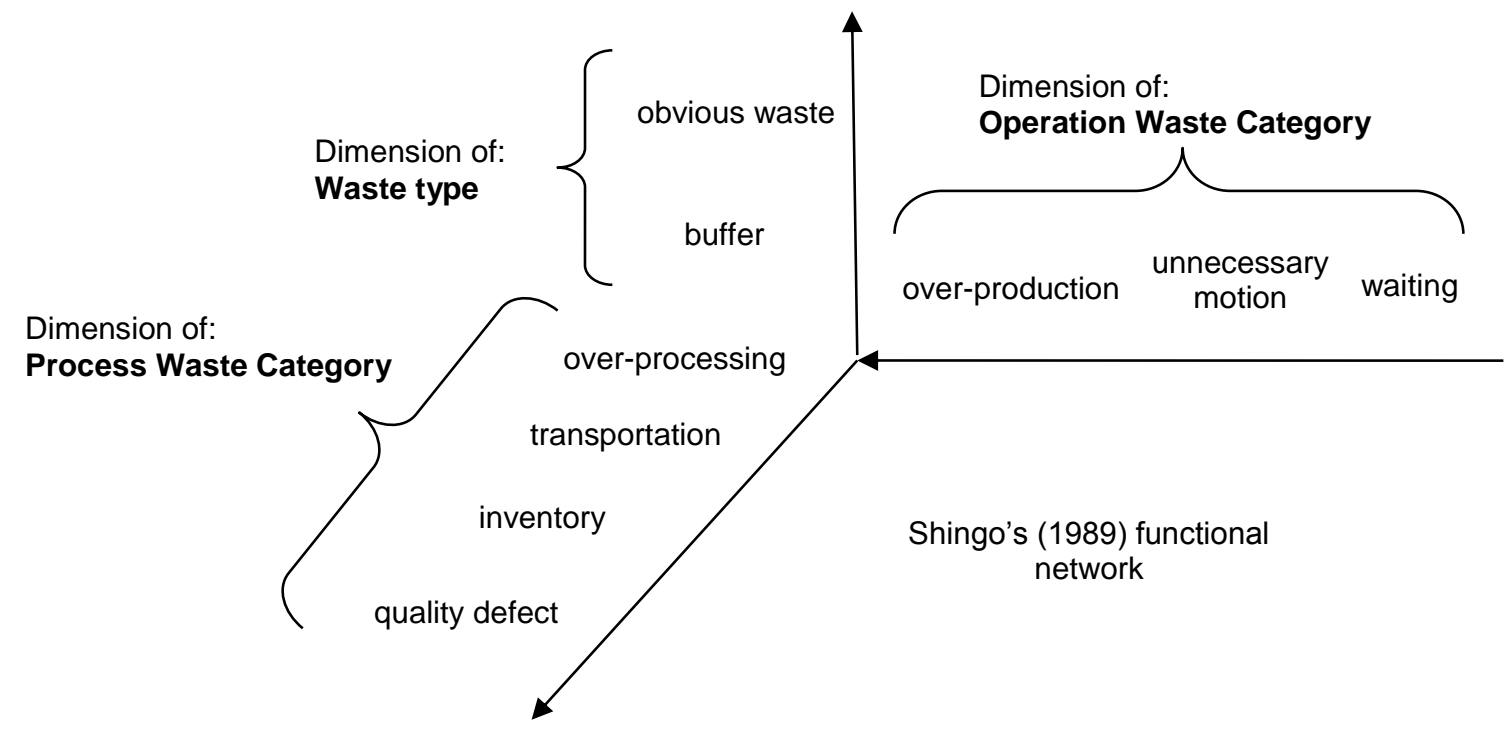

Figure 4: Waste Dimensions - Extending Shingo's (1989) Two-Dimensional Waste Network

This clarifies and operationalizes the common statement that management has to reduce waste. It is hoped that it allows for avoiding the pitfalls associated with 'blind' waste reduction. Above framework characterizes specific wastes. The process/operation category locates the waste in the system. Meanwhile the waste type indicates how reduction can be achieved. Further research is now needed to develop context-specific tools for reducing waste categories/types once they have been identified. 


\section{Conclusions}

Lean has been one of the most important developments in Operations Management. As a consequence, it has received broad research attention. But while most authors and practitioners agree that one of the main principles of lean is waste reduction, the definition of waste itself has received little attention. Although broad reviews of the literature on lean have been presented, there have been no prior reviews specifically on the concept of waste. Instead, it has been assumed that there is a common understanding of what is meant by waste.

We began by asking: What are the waste 'concepts' that can be identified in the literature? And, can a consistent definition of waste be constructed that integrates these concepts? Four different concepts denoted by the term "waste" were put forward in Section 2 of this paper before a systematic literature review explored the use of these concepts. It has been shown that only the classic concept of the seven wastes and the notion of waste as non-value adding activity are widely applied. The other two concepts that use the term waste - based on the concepts of obvious waste and buffers - have not been widely adopted. There appears to be some contradiction in these lines of work - with one viewing waste as being the source of excess inventory and capacity and the other viewing waste as being equal to excess inventory and capacity - and it has remained unclear what they add to earlier work in terms of improving our understanding of waste. However, articles that use the seven wastes concept typically only list the waste categories without providing a definition. Meanwhile, definitions based on the concept of non-value added waste differ widely across studies, are often not meaningful or even in open contradiction with the concept of the seven wastes if applied simultaneously for defining waste.

\subsection{Managerial Implications and Future Research}

Building on our review, we have constructed a consistent definition of waste that integrates the waste concepts used in the literature. Using variability as a demarcation criterion, we then clearly identified two types of waste - obvious waste and buffers. This has important implications for practice since it determines how waste can be reduced. In fact, reducing waste without this distinction may have dire consequences. Management should not reduce waste regardless; rather, three interlinked tasks have to be combined: the elimination of obvious waste; the reduction of variability to transform buffers into obvious waste; and, the balancing of buffers to best achieve performance targets. 
A major step towards reducing/eliminating waste is to be able to see waste. Different conceptualizations can be used to see waste, like different conceptualizations have been used throughout history to see nature. Our framework is another way to see waste; but it is one that we argue improves our understanding of waste and of the causes of waste compared to other frameworks in the literature. Thus, it improves problem diagnosis, which in turn should improve the development of problem solutions. It would be interesting to explore how our framework could enhance the potential of tools as value-stream mapping. Meanwhile, being able to see/define waste is only the first step towards removing waste. Further research is needed to develop context-specific tools for reducing waste categories/types once they have been identified. Another important avenue of future research is to explore the contingencybased nature of our waste framework. While our study is biased towards manufacturing, we argue that our results apply to all kinds of manufacturing and service processes. However, authors such as Hines \& Rich (1997) and Bicheno \& Holweg (2008) have advocated the adaptation of waste concepts to different contexts, such as service systems. Future research, e.g. based on multiple case studies of both service and production processes, would help to resolve this debate, i.e. whether waste concepts do or do not need to be adapted to fit the context. Another important avenue for future research is to explore the inter-relationship between the different types of buffers. We defined a buffer as any waste that cannot be reduced without creating another form of waste. So there must be an inter-relationship between the different buffer types. Understanding the form of this relationship is a major prerequisite to effective buffer balancing (or swapping). Finally, the main limitation of our study is that it only represents our interpretation of the waste concept. We sought to remedy this by presenting the paper to experts and colleagues for their opinion, which triggered a lively debate that significantly enhanced our understanding of waste; however, a broader debate is needed.

\section{References}

Akinc, U., 1993, Selecting a set of vendors in a manufacturing environment, Journal of Operations Management, 11, 2, 107-122.

Arbos, L. C., 2002, Design of a rapid response and high efficiency service by lean production principles: Methodology and evaluation of variability of performance, International Journal of Production Economics, 80, 2, 169-183. 
Arbos, L. C., Santos, J.F., Sanchez, C.V, 2011, The Operations-Time Chart: A graphical tool to evaluate the performance of production systems-From batch-and-queue to lean manufacturing, Computers \& Industrial Engineering, 61, 3, 663-675.

Arbulu, R., Tommelein, I., Walsh, K., Hershauer, J., 2003, Value stream analysis of a re-engineered construction supply chain, Building Research \& Information, 31, 2, 161-171.

Arumugam, V., Antony, J., Douglas, A., 2012, Observation: a Lean tool for improving the effectiveness of Lean Six Sigma, The TQM Journal, 24, 3, 275-287.

Bhamu, J., and Sangwan, K. S., 2014, Lean manufacturing: literature review and research issues, International Journal of Operations \& Production Management, 34(7), 876-940.

Bicheno, J. and Holweg, M., 2008, The Lean Toolbox - Fourth, Edition, PISCIE Books, Buckingham.

Bortolotti, T., and Romano, P., 2012, 'Lean first, then automate': a framework for process improvement in pure service companies. A case study, Production Planning \& Control, 23, 7 , 513-522.

Browning, T.R., 2003, On customer value and improvement in product development processes, System Engineering, 6, 1, 49-61.

Canel, C., Rosen, D., Anderson, E. A., 2000, Just-in-time is not just for manufacturing: a service perspective, Industrial Management \& Data Systems, 100, 2, 51-60.

Chongwatpol, J., and Sharda, R., 2013, Achieving Lean Objectives through RFID: A SimulationBased Assessment, Decision Sciences, 44, 2, 239-266.

Dahlgaard, J. J., and Dahlgaard, S. M. P., 2002, From defect reduction to reduction of waste and customer/stakeholder satisfaction (understanding the new TQM metrology), Total Quality Management, 13, 8, 1069-1086.

Dart, R. C., 2011, Can lean thinking transform American health care?, Annals of Emergency Medicine, $57,3,279-281$.

de Treville, S., and Antonakis, J. 2006, Could lean production job design be intrinsically motivating? Contextual, configurational, and levels-of-analysis issues, Journal of Operations Management, 24, $2,99-123$.

Deming, E.W., 1986, Out of the crisis, $2^{\text {nd }}$ Edition, Massachusetts Institute of Technology, Cambridge, MA.

Dennis, P., 2007, Lean Production simplified: A plain-language guide to the world's most powerful production system, Productivity Press.

Eswaramoorthi, M., Kathiresan, G. R., Prasad, P. S. S., Mohanram, P. V., 2011, A survey on lean practices in Indian machine tool industries, The International Journal of Advanced Manufacturing Technology, 52, 9-12, 1091-1101.

Feyerabend, P., 2010, Against method: Outline of an anarchistic theory of knowledge, 4th edn. London: Verso Books. 
Gorman, M. F., Hoff, J., Kinion, R., 2009, ASP, the art and science of practice: tales from the front: case studies indicate the potential pitfalls of misapplication of lean improvement programs, Interfaces, 39, 6, 540-548.

Gudem, M., Steinert, M., Welo, T., Leifer, L., 2013, Redefining customer value in lean product development design projects, Journal of Engineering, Design and Technology, 11, 1, 71-89.

Harrison, A., 1992, Just-in-Time: manufacturing in perspective. Prentice Hall.

Hill, T., 1993, Manufacturing strategy, Macmillan, Basingstoke: Hampshire.

Hines, P., and Rich, N., 1997, The seven value stream mapping tools, International Journal of Operations \& Production Management, 17, 1, 46-64.

Hines, P., Holweg, M., Rich, N., 2004, Learning to evolve: a review of contemporary lean thinking, International Journal of Operations \& Production Management, 24, 10, 994-1011.

Holweg, M., 2007, The genealogy of lean production, Journal of Operations Management, 25, 2, 420 437.

Hopp, W. J., and Spearman, M. L., 2004, To pull or not to pull: what is the question?, Manufacturing \& Service Operations Management, 6, 2, 133-148.

Jainury, S. M., Ramli, R., Rahman, M. N. A., Omar, A., 2013, Design Concepts in Set Parts Supply Implementation, Research Journal of Applied Sciences, Engineering and Technology, 6, 19, 3682-3685.

Jasti, N. V. K., and Kodali, R., 2015, Lean production: literature review and trends, International Journal of Production Research, 53, 3, 867-885.

Karim, A., and Arif-Uz-Zaman, K., 2013, A methodology for effective implementation of lean strategies and its performance evaluation in manufacturing organizations, Business Process Management Journal, 19, 1, 169-196.

Krippendorff, K., 2003, Content Analysis: An introduction to its methodology, $2^{\text {nd }}$ Ed. Sage Publications.

Lapré, M. A., Mukherjee, A. S., Van Wassenhove, L. N., 2000, Behind the learning curve: Linking learning activities to waste reduction, Management Science, 46, 5, 597-611.

Li, D., and O'Brien, C., 1999, Integrated decision modelling of supply chain efficiency, International Journal of Production Economics, 59, 1, 147-157.

Liker, J. K., 2003, The Toyota Way, McGraw-Hill.

Liker, J. K., and Meier, D., 2006, The Toyota Way Field book: A Practical Guide for Implementing Toyota's 4Ps, McGraw-Hill, New York.

Lim, K., Ahmed, P. K., Zairi, M., 1999, Managing waste and looking beyond: the IMI approach, The TQM Magazine, 11, 5, 304-310.

Liu, S., Leat, M., Moizer, J., Megicks, P., Kasturiratne, D., 2013, A decision-focused knowledge management framework to support collaborative decision making for lean supply chain management, International Journal of Production Research, 51, 7, 2123-2137. 
MacDuffie, J.P. and Helper, S., 1997, Creating lean suppliers: diffusing lean production through the supply chain, paper presented at International Motor Vehicle Program (IMVP) FY'97 IMVP working papers.

Maslaric, M., Backalic, T., Nikolicic, S., Mircetic, D., 2013, Assessing the trade-off between lean and resilience through supply chain risk management, International Journal of Industrial Engineering and Management, 4, 4, 229-236

Moyano-Fuentes, J., and Sacristán-Díaz, M., 2012, Learning on lean: a review of thinking and research, International Journal of Operations \& Production Management, 32, 5, 551-582.

Narasimhan, R., Swink, M., Kim, S. W., 2006, Disentangling leanness and agility: an empirical investigation, Journal of Operations Management, 24, 5, 440-457.

Oliver, N., Schab, L., Holweg, M., 2007, Lean principles and premium brands: conflict or complement?, International Journal of Production Research, 45, 16, 3723-3739.

Ohno, T.,1988, Toyota production system: beyond large scale production, Productivity Pres, Cambridge, MA.

Papadopoulou, T. C., and Özbayrak, M., 2005, Leanness: experiences from the journey to date, Journal of Manufacturing Technology Management, 16, 7, 784-807.

Petersen, K., and Wohlin, C., 2010, Software process improvement through the Lean Measurement (SPI-LEAM) method, Journal of Systems and Software, 83, 7, 1275-1287.

Pheng, L. S., and Hui, M.S., 1999, The application of JIT philosophy to construction: a case study in site layout, Construction Management \& Economics, 17, 5, 657-668.

Poppendieck, M., and Cusumano, M. A., 2012, Lean software development: A tutorial, Software, IEEE, 29, 5, 26-32.

Protzman, C., Mayzell, G., and Kerpchar, J., 2010, Leveraging Lean in Healthcare: Transforming Your Enterprise into a High Quality Patient Care Delivery System, $1^{\text {st }}$ Ed. Productivity Press.

Radnor, Z., 2010, Transferring lean into government, Journal of Manufacturing Technology Management, 21, 3, 411-428.

Ramesh, V., and Kodali, R., 2012, A decision framework for maximising lean manufacturing performance, International Journal of Production Research, 50, 8, 2234-2251.

Rawabdeh, I. A., 2005, A model for the assessment of waste in job shop environments, International Journal of Operations \& Production Management, 25, 8, 800-822.

Sahoo, A.K., Singh, N.K., Shankar, R and Tiwari, M.K., 2008, Lean philosophy: implementation in a forging company, International Journal of Advanced Manufacturing Technology, 36, 451-462.

Schmenner, R. W., and Swink, M. L., 1998, On theory in operations management, Journal of Operations Management, 17, 1, 97-113.

Schonberger, R. J., 1982, Japanese Manufacturing Techniques: Nine Hidden Lessons in Simplicity, The Free Press, New York. 
Shah, R., and Ward, P. T., 2003, Lean manufacturing: context, practice bundles, and performance, Journal of Operations Management, 21, 2, 129-149.

Shah, R., and Ward, P. T., 2007, Defining and developing measures of lean production. Journal of Operations Management, 25, 4, 785-805.

Shewart, W.A., 1931, Economic Control of Quality of Manufactured Product, 50 ${ }^{\text {th }}$ Anniversary Commemorative Reissue, American Society for Quality Control, Chelsea, MI.

Shiba, S., and Walden, D, 2001, Four Practical Revolutions in Management: Systems for Creating Unique Organizational Capability, $2^{\text {nd }}$ Edition, Productivity Press.

Shingo, S., 1989, A Study of the Toyota Production System from an Industrial Engineering Viewpoint, Cambridge, MA: Productivity Press.

Tomašević, I., and Slović, D., 2013, Facilitating wasteful activities discovery in pure service environment through usage of process mining, International Journal of Industrial Engineering and Management, 4, 4, 199-206.

Tranfield, D., Denyer, D., Smart, P., 2003, Towards a methodology for developing evidence-informed management knowledge by means of systematic review, British Journal of Management, 14, 3 , 207-222.

Tserng, H. P., Yin, S. Y. L., Ngo, T. L., 2013, A Lean Prebid Planning Model for Construction Contractors: A Case Study in Vietnam, Journal of Marine Science and Technology, 21, 4, 430441.

Wang, L., Ming, X. G., Kong, F. B., Li, D., Wang, P. P., 2011, Focus on implementation: a framework for lean product development, Journal of Manufacturing Technology Management, 23, 1, 4-24.

Weber, M., 2014, Wirtschaft und Gesellschaft: Soziologie, Studienausgabe der MaxWeber Gesamtausgabe Band I/23, Mohr Siebeck, Tubingen.

Wee, H. M., and Wu, S., 2009, Lean supply chain and its effect on product cost and quality: a case study on Ford Motor Company, Supply Chain Management: An International Journal, 14, 5, 335 341.

Womack, J. P., and Jones, D. T., 1996, Lean thinking: Banish waste and create wealth in your organization, Simon and Shuster, New York.

Womack, J. P., Jones, D. T., Roos, D., 1990, The machine that changed the world. Simon and Schuster.

Zhou, B., 2012, Lean principles, practices, and impacts: a study on small and medium-sized enterprises (SMEs), Annals of Operations Research, 1-18. 